\title{
Nitrogen Fertilizer Sources: What does the future hold for citrus producers ${ }^{1}$
}

Thomas Obreza, Larry Parsons, and Kelly Morgan²

\section{Introduction}

Florida citrus growers are well aware that nitrogen $(\mathrm{N})$ is the single most important nutrient applied as a fertilizer to assure maximum yield and fruit quality. Most growers are also aware of the substantial $\mathrm{N}$ fertilizer price fluctuations that have occurred during the past few years (Table 1). Ammonium nitrate, the workhorse $\mathrm{N}$ fertilizer used by citrus growers for decades, has been affected as much as any $\mathrm{N}$ source. Typical questions on the minds of growers are: why has this happened, will it continue, and will economics force a change in the type of $\mathrm{N}$ fertilizer we use?

\section{It's all about natural gas}

Twelve years ago, the U.S. was the world's largest exporter of $\mathrm{N}$ fertilizer; now we are the largest importer. More than half the $\mathrm{N}$ our farmers now use comes from places like Trinidad, Russia, and the Persian Gulf rather than the Midwest or Southeastern U.S. Why are we importing so much? It all starts with production of anhydrous ammonia $\left(\mathrm{NH}_{3}\right)$, from which almost all familiar solid $\mathrm{N}$ fertilizers like ammonium nitrate are made. Ammonia is produced by combining $\mathrm{N}$ from the air with hydrogen at high temperature and pressure. The hydrogen is derived from natural gas, which accounts for around $80 \%$ of the production cost. Natural gas prices have been destabilized by increased competition (electric power generation, home heating) in the long term and Gulf of Mexico hurricanes in the short term. This situation has put massive stress on the fertilizer industry. Since natural gas is so much cheaper in other parts of the world, ammonia producers in the U.S. have not been able to compete, so many of our domestic production facilities have shut down or closed for good. For example, in early 2009 the price of natural gas in the U.S. was around $\$ 8.00$ per million Btu. Worldwide, the price was around $\$ 3.00$ in Trinidad, $\$ 1.60$ in Russia, $\$ 0.50$ in Venezuela, and $\$ 0.60$ in the Middle East. With recent wide fluctuations in the cost of crude oil and natural gas, it is hard to predict the effect on long-term $\mathrm{N}$ fertilizer prices. Regardless, it does not take an economics scholar to realize that, unless alternatives are found, our future demand for $\mathrm{N}$ fertilizer will increasingly be met by imports.

1. This document is SL-238, a fact sheet of the Soil and Water Science Department, Florida Cooperative Extension Service, Institute of Food and Agricultural Sciences, University of Florida. Original publication date February, 2006. Revised February, 2009. Visit the EDIS Web Site at http://edis.ifas.ufl.edu.

2. Thomas Obreza, professor, Soil and Water Science Department, Gainesville, Larry Parsons, professor, Citrus Research and Education Center, Lake Alfred, FL; and Kelly Morgan, assistant professor, Southwest Florida Research and Education Center, Immokalee, FL; Florida Cooperative Extension Service, Institute of Food and Agricultural Sciences, University of Florida, Gainesville, FL 32611-0290.

The Institute of Food and Agricultural Sciences (IFAS) is an Equal Opportunity Institution authorized to provide research, educational information and other services only to individuals and institutions that function with non-discrimination with respect to race, creed, color, religion, age, disability, sex, sexual orientation, marital status, national origin, political opinions or affiliations. U.S. Department of Agriculture, Cooperative Extension Service, University of Florida, IFAS, Florida A. \& M. University Cooperative Extension Program, and Boards of County Commissioners Cooperating. Millie Ferrer, Interim Dean 


\section{What kind of $\mathbf{N}$ is being imported?}

During the period from 2000 to 2006, ammonia imports to the U.S. increased $115 \%$, but urea imports increased even more. Also, the share of

U.S.-produced ammonia in the country's aggregate supply dropped from 80 to $55 \%$, while the share from imports increased from 15 to $42 \%$. Although $\mathrm{NH}_{3}$ is still the form of $\mathrm{N}$ preferred in this country, it must be stored under pressure and is expensive to keep in large quantities. Urea, on the other hand, is relatively cheap to move and easy to store. While $\mathrm{NH}_{3}$ is not going to disappear by any means, urea is emerging as the $\mathrm{N}$ source preferred by overseas shippers.

\section{What effect will this have on $\mathbf{N}$ fertilizer choices?}

The future of our ammonium nitrate supply is in doubt for several reasons. First, its storage is a security issue due to its explosive nature. Second, it cannot be shipped long distances because it does not hold up well in high humidity. Third, it is unclear as to how much imported ammonia can be converted to ammonium nitrate considering the degree to which domestic production has been curtailed. Citrus growers used to applying ammonium nitrate in their groves may find themselves in an economic quandary in the near future. Ammonium nitrate will not disappear, but restricted availability may make the price of alternative $\mathrm{N}$ sources much more attractive. This possibility brings up the next question: Do we need to manage these materials differently?

\section{Managing water-soluble $\mathbf{N}$ fertilizers}

The two major, non-specialty, water-soluble $\mathrm{N}$ fertilizer alternatives to ammonium nitrate are ammonium sulfate and urea. While ammonium sulfate has been commonly used to fertilize Florida citrus for many years, urea applied as a solid material has not. Let's briefly compare and contrast these materials and ammonium nitrate with respect to properties that affect how they should be managed to fertilize citrus:

- Ammonium nitrate is easily blended into complete fertilizers for routine application to citrus as dry materials (for example, a 15-5-15 material made by combining ammonium nitrate, concentrated superphosphate and muriate of potash). Dry fertilizers containing this $\mathrm{N}$ source cannot be stored for long periods because of its tendency to "melt" in high humidity. In addition, ammonium nitrate is not compatible with urea in dry blends because the combination turns to liquid immediately. Loss of $\mathrm{N}$ by ammonia volatilization following surface application of ammonium nitrate is not considered to be significant unless the soil $\mathrm{pH}$ is above 7 . This $\mathrm{N}$ source is easily dissolved in water to make solutions that are used for fertigation, either alone or in combination with soluble potassium (for example, an 8-0-8 true solution fertilizer).

- Ammonium sulfate is also easily blended with other fertilizer materials, including urea, to make complete dry fertilizers. These blends are very stable and can be stored for longer periods because they do not melt in high humidity. Ammonium sulfate does not dissolve as quickly as ammonium nitrate or urea, so it is seldom used to make $\mathrm{N}$ solutions. It has the highest acidifying power of the $\mathrm{N}$ sources considered here, so soil $\mathrm{pH}$ should be monitored if ammonium sulfate is routinely used and lime applied if necessary to counteract low $\mathrm{pH}$. It also contains $24 \%$ sulfur, which is an important plant nutrient. The cost of ammonium sulfate is not affected by natural gas prices nearly as much as ammonium nitrate and urea are, because this fertilizer is a by-product of industrial steel-making and synthetic fiber production. Currently, ammonium sulfate that is generated as a by-product of industrial process like steel-making supplies $100 \%$ of its demand as fertilizer in the U.S.

- Urea is more water-soluble than ammonium nitrate, but it is not affected by humidity to the same degree. After application, it quickly converts to ammonium carbonate in the soil. The key hazard associated with the use of solid urea to fertilize citrus is loss of $\mathrm{N}$ through ammonia volatilization following surface application. For example, as much as 20 to $40 \%$ of the urea-N applied to pastureland can be lost through volatilization, depending on environmental conditions. It is extremely important to irrigate or soil-incorporate urea immediately after a 
surface application. Urea is commonly used to make fertilizer solutions. If fertigated, volatilization from urea would not occur, since irrigation water would move it into the soil.

\section{Let's see all that in a nutshell}

Economics and fertilizer availability may cause Florida citrus growers to re-think the selection and management of $\mathrm{N}$ materials. Limited availability or high cost of ammonium nitrate will likely stimulate increased use of ammonium sulfate or urea. Growers must be aware of the different properties and behavior of these fertilizers, and should be prepared to change some management practices, if necessary, to maintain high fertilization efficiency. 
Nitrogen Fertilizer Sources: What does the future hold for citrus producers?

Table 1. Changing costs of three $\mathrm{N}$ fertilizer materials in the southeastern United States.

\begin{tabular}{||l|c|c|c|c|c|c|c|c||}
\hline \hline \multirow{2}{*}{ Material } & \multicolumn{2}{|c|}{ Jan 2009 } & \multicolumn{2}{c|}{ Jan 2008 } & \multicolumn{2}{c|}{ Oct 2005 } & \multicolumn{2}{c||}{ Oct 2004 } \\
\cline { 2 - 9 } & $\begin{array}{c}\text { Cost per } \\
\text { ton } \\
(\$)\end{array}$ & $\begin{array}{c}\text { Cost per } \\
\mathrm{lb} \text { of } \mathrm{N}(\$)\end{array}$ & $\begin{array}{c}\text { Cost per } \\
\text { to } \\
(\$)\end{array}$ & $\begin{array}{c}\text { Cost per } \\
\mathrm{lb} \text { of } \mathrm{N}(\$)\end{array}$ & $\begin{array}{c}\text { Cost per } \\
\text { ton } \\
(\$)\end{array}$ & $\begin{array}{c}\text { Cost } \\
\text { per Ib } \\
\text { of } \mathrm{N}(\$)\end{array}$ & $\begin{array}{c}\text { Cost per } \\
\text { ton } \\
(\$)\end{array}$ & $\begin{array}{c}\text { Cost per } \\
\mathrm{lb} \text { of } \mathrm{N}(\$)\end{array}$ \\
\hline $\begin{array}{l}\text { Ammonium } \\
\text { nitrate }(34 \% \\
\mathrm{N})\end{array}$ & $250-300$ & 0.40 & $390-400$ & 0.59 & $275-285$ & 0.41 & $200-205$ & 0.30 \\
\hline $\begin{array}{l}\text { Ammonium } \\
\text { sulfate } \\
(21 \% \mathrm{~N})\end{array}$ & $150-175$ & 0.39 & $280-290$ & 0.68 & $165-168$ & 0.40 & $160-165$ & 0.39 \\
\hline $\begin{array}{l}\text { Urea } \\
(46 \% \mathrm{~N})\end{array}$ & $350-360$ & 0.39 & $460-480$ & 0.51 & $295-305$ & 0.33 & $245-250$ & 0.27 \\
\hline \hline
\end{tabular}

